\title{
A Meta-Analysis Study on Gender Differences in Psychological Resilience Levels
}

\section{Psikolojik Dayanıklılık Düzeylerinde Cinsiyet Farklılıkları Üzerine Bir Meta Analiz Çalışması}

\author{
Ayşe Gök ${ }^{1}$, Esin Yılmaz Koğar ${ }^{2}$
}

\begin{abstract}
:
The general purpose of the study is to provide a quantitative summary of the findings of studies that address the psychological resilience levels of individuals in terms of gender differences. This study includes a review of the relevant literature, the stages of meta-analysis research, analysis findings got from the included studies, discussions on the results of the findings, and finally recommendations for future psychological resilience research. Because of the literature review, 30 thesis and article-type researches were selected for meta-analysis under the inclusion criteria of the study. The effect size was calculated for each study using the non-standardized mean difference method. It was concluded that there was no publication bias in the studies selected according to the funnel plot and Egger test findings. As a result of the analysis made according to the random effects model, it was determined that the effect size for gender has a significant effect on the psychological resilience level of the individuals, and the results are in favor of men. Because of the heterogeneity test, a moderate level of heterogeneity was found between studies. Reasons for this heterogeneity were the type of publication, the study group, the way the data were collected, and the total number of participants. It was found that only the study group variable among these variables can lead to heterogeneity.
\end{abstract}

Keywords: Psychological Resilience, Gender Differences, Random Effects Model, Meta-Analysis

\footnotetext{
${ }^{1}$ Research Assistant., Department of Psychological Counselling and Guidance, Niğde Ömer Halisdemir University, NiğdeTurkey, Orcid İd: https://orcid.org/ 0000-0002-7544-5800

${ }^{2}$ Assistant Prof. Dr., Department of Educational Sciences, Department of Niğde-Turkey, Orcid İd: https://orcid.org/ 00000001-6755-9018
}

Address of Correspondence/Yazşma Adresi: Department of Psychological Counselling and Guidance, Niğde Ömer Halisdemir University, Niğde-Turkey., E-mail: aysegok1993@ hotmail.com

Date of Received/Geliş Tarihi: 13.04.2021, Date of Revision/Düzeltme Tarihi: 06.05.2021, Date of Acceptance/Kabul Tarihi: 10.05.2021, Date of Online Publication/Çevirimiçi Yayın Tarihi: 01.06.2021

Citing/Referans Gösterimi: Koğar Yılmaz, E., Gök, A. (2021). A Meta-Analysis Study on Gender Differences in Psychological Resilience Levels., Cyprus Turkish Journal of Psychiatry \& Psychology, 3(2): 132-143.

(C) 2021 The Author(s). Published by Cyprus Mental Health Institute / Cyprus Turkish Journal of Psychiatry and Psychology (www.ktppdergisi.com). This article is an open access article distributed under the terms and conditions of the Creative Commons Attribution 4.0 license which permits use, sharing, adaptation, distribution and reproduction in any medium or format, provided the original work is properly cited and is not used for commercial purposes. https://creativecommons.org/licenses/by-nc-sa/4.0/ 


\section{Öz:}

Araştırmanın genel amacı, cinsiyet farklılıkları açısından bireylerin psikolojik dayanıklılık düzeylerini ele alan çalışmaların bulgularının nicel bir özetini sunmaktır. Bu çalışma, ilgili literatürün gözden geçirilmesini, metaanaliz araştırmasının aşamalarını, dahil edilen çalışmalardan elde edilen analiz bulgularını, bulguların sonuçları üzerine tartışmaları ve son olarak gelecekteki psikolojik dayanıklılık araştırmaları için önerileri içermektedir. Literatür taraması sonucunda ve çalışmaya dahil edilme kriterleri kapsamında meta-analiz için 30 adet tez ve makale tipi araştırma seçilmiştir. Etki büyüklügü̈, standartlaştııılmamış ortalama fark yöntemi kullanılarak her çalışma için hesaplanmıştır. Huni grafiği ve Egger testi bulgularına göre seçilen çalışmalarda yayın yanlılı̆̆ olmadığı sonucuna varılmıştır. Rastgele etkiler modeline göre yapılan analiz sonucunda, cinsiyete göre etki büyüklügünün bireylerin psikolojik dayanıklılık düzeyi üzerinde anlamlı bir etkiye sahip olduğu ve sonuçların erkekler lehine olduğu belirlenmiştir. Heterojenlik testi nedeniyle, çalışmalar arasında orta düzeyde bir heterojenlik bulunmuştur. Bu heterojenliğin nedenleri, yayın türü, çalışma grubu, verilerin toplanma şekli ve toplam katılımcı sayısıdır. Bu değişkenlerden sadece çalışma grubu değişkeninin heterojenliğe yol açabileceği bulunmuştur.

Anahtar Kelimeler: Psikolojik Sağlamlık, Cinsiyet Farklılıkları, Rastgele Etkiler Modeli, Meta-Analiz

\section{Introduction}

Psychological resilience (PR) has long been a popular concept in research. In daily life, many individuals have to cope with many difficulties because of stressful experiences they have lived. It is known that situations such as war, natural disaster, economic crisis, and infectious disease epidemics that penetrate societies have negative effects on the mental health of individuals (Kang, 2020). The virus epidemic, defined as the New Coronavirus Disease (COVID-19), which took effect all over the world and appeared with respiratory symptoms in Wuhan Province, China in late December, led to a global health crisis (World Health Organization [WHO], 2020). According to Bonanno and Mancini (2008), the psychological and physiological effects brought about by such traumatic events almost always cause permanent emotional damage in individuals. During this epidemic, individuals struggled with the psychological, sociological, and economic consequences brought about by the epidemic they had to struggle with the biological effects of the virus. Besides these, the uncertainty and limitations of the epidemic process are some of the most difficult situations for individuals to deal with psychologically. Preparing for an unknown situation poses a threat to individuals both physically and mentally (State University of New York-Institute for Disaster Mental Health [SUNY-IDMH], 2020). One of the most common emotional responses in infectious disease outbreaks is fear. Individuals use a variety of coping strategies to cope with such life threats (Le Doux, 2012; Van Bavel, 2020). PR, as a dynamic process that comes into play at this point and enables such negative experiences to be overcome healthily, has been the subject of many studies today. When the relevant literature is examined, studies that deal with the concept of psychological resilience (Carriedo, 2020; He, 2020; Karaşar \& Canl1, 2020; Kimhi, 2020; Kul, 2020; Lissoni, 2020; Petzold, et al., 2020; Ran, 2020; Yıldırım \& Arslan, 2020).

Some studies on PR revealed that women are more resilient, others are men. These variations in findings are probably related to the fact that these studies used small homogeneous samples. For this reason, the reason behind the mixed results can be determined over a data set that combines the data of different studies using a metaanalytical approach. The study is important to examine
PR issue, on which many studies have been conducted in recent years, through the findings of different studies, because of many problems brought by today's world. There are previous meta-analysis studies on this subject (Ar1 \& Çark1t, 2020; Joyce, 2018; Lee, 2013; Oshio, 2018). However, this current study focuses only on studies conducted on a Turkish sample and addressing gender differences. A meta-analysis of studies carried out in Turkey earlier this housing also is performed (Ar1 \& Çarkıt, 2020) related work has only been carried out on a thesis published in 2019. In this study, both articles and theses were focused on, studies in 2018-2020 were examined, and then moderator analyzes were made to investigate the reason for heterogeneity. In this respect, it can be said that this research is more comprehensive. Also, the COVID-19 outbreak that emerged in 2020 led many researchers to work on the psychological resilience of individuals (Artan et al., 2020; Bilge \& Bilge, 2020; Bozdağ, 2020; Demir \& Çiftçi, 2020; Kasapoğlu, 2020; Kımter, 2020; Yazıc1-Çelebi, 2020). Therefore, another important feature of this meta-analysis study is that it also includes studies conducted during the COVID-19 outbreak. In this study, previous studies that address PR levels according to gender differences were systematically reviewed and the findings of different studies about gender group differences in PR were focused. The differences in the conditions and quality measures of the studies for PR may have affected the research findings in this area. For this reason, it is important to examine what the result is when the findings of different studies are combined.

The primary purpose of this study is to provide a quantitative synthesis of studies examining gender differences in PR. This study focuses on the following key research questions:

1. Is there a statistically significant difference in the psychological resilience level of individuals according to gender groups?

2. Could the gender group differences in individual studies on psychological resilience of individuals be due to study characteristics such as the type of publication, the study group, the way the data were collected, and the total number of participants? 


\section{Literature Review}

\section{Psychological Resilience}

Psychological resilience (PR) is the ability to adapt positively to difficult living conditions and to maintain mental health despite negative life experiences (Hermann, 2011). PR is referred to in different names such as resilience (Öğmiş, 2001), self-recovery (Masten, 2001; Terzi, 2005; Walsh, 2006), or resilience (Kobasa, 1979), coping with the difficulties of life and in the meantime. In general, it is accepted as an individual's ability to establish a complete bond with himself/herself (Ramirez, 3007). Although there is no common definition regarding the concept of psychological resilience in the relevant literature, it is possible to encounter different definitions from each other. There are different definitions regarding the concept of psychological resilience in the literature. Masten (2001) stated that PR is seeing positive results despite serious threats to the development and adaptation of the individual. In another definition, PR is considered as a dynamic process that includes positive adaptation in a context in which difficulties prevail (Luthar, 2000). Although there is no common definition of the concept of PR, two basic points where these definitions meet are pointed out (Hermann, 2011). Various factors and systems, the first of these points, are accepted as dynamic processes that increase the PR of individuals against difficult life experiences. PR may be context and time-specific and not available in all areas of life. Here, it is possible to mention many factors that frequently interact with each other, including biological, psychological, and dispositional features that affect PR, social support, and other features of social systems (family, school, and friends) (Hermann, 2011). These factors are collected in three groups: individual, familial, and environmental.

\section{Individual factors}

Personality traits (openness, extroversion, and intelligibility), internal locus of control, self-efficacy, self-esteem, and optimism are individual protective factors for psychological resilience. Besides these features such as intellectual functionality, cognitive flexibility, social bonding, emotion regulation skills, and positive emotions, gender, spirituality, hope, and adaptability are factors that support psychological resilience (Joseph \& Linley, 2006; Hermann, 2011; Kumpfer, 1999). Sometimes, risks and problems can become that individuals cannot overcome individually. These types of situations are individual risk factors that can have negative effects on the psychological well-being of individuals, unlike individual protective factors. Being born with preterm birth, negative life experiences. Examples of individual risk factors are chronic mental or physical illness and having an incompatible or shy temperament (Bradley, 1994; Masten, 1999; Windle, 2011).

\section{Familial factors}

When the relevant literature was examined, it was seen that characteristics such as positive parent-child relationship, high and realistic expectations for the child, living with the family, and well-educated parents are familial protective factors for psychological resilience (Gizir, 2007; Hermann, 2011; Öz \& Y1lmaz, 2009). While these protective factors function to soften, reduce or eliminate the effect of risk or difficulty (Masten, 1994), familial risk factors create the opposite effect. It is known that this situation poses a threat to their psychological resilience, especially when individuals are not given good care and maltreatment during childhood (Werner, 1995). Besides these, having parents with mental or physical chronic diseases, the divorce of parents, adoption, parental death or having a single parent and domestic violence are other familial risk factors (Cicchetti \& Rogosch, 2007; Gizir, 2007).

\section{Environmental factors}

At the micro-environmental level, social support, including relationships with family and peers, is one of the leading environmental protective factors associated with psychological resilience. Secure attachment with the mother, the stability of the family, a secure relationship with a realistic parent, the absence of depression or substance addiction in the parents is also considered as other environmental protective factors (Luthar, 2000; Luthar \& Cicchetti, 2000). At the macro-systemic level, social factors such as excellent schools, social services, sports and artistic opportunities, cultural factors, spirituality, and freedom from violence contribute to the psychological resilience of individuals (Gizir, 2007). Environmental risk factors, which pose a significant threat to individuals' psychological well-being, also have an undeniable effect.

Financial difficulties, poverty, child neglect and abuse, social traumas such as war and natural disasters, social violence, and family disasters are among the most prominent environmental risk factors. Environmental risk factors, like other risk factors, go beyond the individual capacities of individuals and negatively affect their psychological resilience (Norris, 2008).

Risk factors emerging because of stressful life experiences and protective factors that mitigate the negative effects of risk contribute to the concept of psychological resilience, which is also defined as a developmental process (Karairmak, 2006). Although protective and risk factors that impact psychological resilience are divided into individual, familial and environmental groups, there is an interactive relationship between them. For example, an individual's personality traits or gender may affect relationships with others inside or outside the family (Mandleco, 2000)

\section{Gender and Psychological Resilience}

The effect of gender on PR has been tested in many studies, but no consensus was observed in these study results. Zhang (2018) argued that the gender variable moderates the negative effects of resilience and perceived social support on mental health. In some studies, it was found that the psychological resilience levels of women were higher (Davidson et al., 2005; Fonagy et al., 1994; McGloin \& Widom, 2001; Önder \& Gülay, 2008; Werner, 1990). In some studies (Campbell-Sills, 2009; Lee, 2008; Oktan, 2008; Stein, 2009), it was found that men have higher PRthan women. Several opinions have been raised about the typical lower scores of women on PRcriteria than men. They argue that the current conceptualizations of PRdo not reflect how gender roles, 
social expectations, perceptions, and environmental factors interact to differently shape the experiences and reactions of women and men to challenges (Hirani, 2016). In some studies, no relationship was observed between gender and PR (Aydoğdu, 2015; Bozgeyikli, 2017; Eryllmaz, 2012; Rew, 2001).

\section{Potential factors that may affect research findings}

1. Type of Publication: The data of the present study include both articles and theses. Because previous studies have shown that effect sizes reported in theses are smaller than those reported in articles, potentially reflecting publication bias (Ferguson \& Brannick, 2012). For this reason, the moderator role of the type of publication was examined in the differentiation of psychological resilience levels of individuals according to the gender variable.2. Study Group: Conducting studies over original study groups may cause diversity in the findings of individuals' PR levels regarding gender differences. Therefore, the moderator role of the type of study group in the differentiation of the PR level of individuals according to the gender variable was examined.

3. The Way of Collecting Data: Because online applications offer the opportunity to reach more people and the way they reach the participants because of epidemic diseases, the way researchers collect data vary. Researchers can collect their data using paper and pencil, online, or mixed applications using both methods. For this reason, the moderator role of the way data is collected in the differentiation of PR of individuals according to the gender variable was examined.

4. Total Number of Participants: The weights used in calculating the effect sizes are affected by the sample size of the studies. The largest weight percentage belongs to the study with the largest number of observations. For this reason, the moderator role of the total number of participants in the differentiation of the psychological resilience of individuals according to the gender variable was examined.

\section{Meta-Analysis}

Meta-analysis is a statistical procedure that combines the results of several independent studies on the same subject (Glass, 1976). Well-structured meta-analysis studies; it is important because of their features such as allowing a more aim evaluation based on individual results, reaching a more precise estimation of a treatment effect, and being able to explain the heterogeneity between the results of individual studies (Egger \& Smith, 1997).

By calculating the effect sizes based on the findings of the studies determined within a meta-analysis, the findings are transformed into a common metric. The effect size is calculated based on average values, proportions, and correlation coefficients, and the method to be used is decided according to the data of the selected studies in line with the purpose of the study (Littel, 2008). After this stage, the model selection comes.

There are two models: fixed effect model or randomeffects model. In the fixed effect model, it is assumed that there is only one real effect size underlying all studies in the analysis, while under the random-effects model, the actual effect may vary from study to study (Borenstein, 2009). Then, the heterogeneity of the effect sizes got from the studies is checked and one of the most used statistics for this purpose is the Q statistics.

\section{Method}

\section{Literature Review and Inclusion Criteria}

In this study, a literature review was conducted on studies that examined the psychological resilience levels of individuals in terms of gender differences and were conducted between 2018-2020. This search was carried out through databases such as Web of Science, ProQuest, EBSCO, PsycINFO, ERIC, Tr Index, Google Scholar, and the National Thesis Data Center of the Council of Higher Education. Keywords used for search comprise words such as "psychological resilience", "resilience", "Brief Psychological Resilience Scale", "psychological resilience", "resilience", "resilient", "The Brief Psychological Resilience Scale". Because of the concern that the results got from this study may reduce the accuracy, only theses and articles published in peerreviewed journals were included in the study. Also, the working group chose Turkey as a language of publication and are only examined studies that Turkish and English.

The studies reached the next stage, which may create the potential for the study, were first examined according to the scale they used to measure psychological resilience. In studies conducted in Turkey, although there are many scales in the literature to measure the psychological resistance, mostly Smith and the six-point development by friends (2008) The Brief Psychological Resilience Scale (BPRS) is used. For this reason, only studies using the BPRS were selected to measure psychological resilience. Because the different results in meta-analysis studies maybe because of the psychometric properties of the measurement tool used. The original language of the scale was English and adaptation studies were made in different countries and translated into many languages (de Holanda Coelho, 2016; Doğan, 2015; Fung, 2020; Konaszewski, 2020; Liu \& Lim, 2020; Macovei; 2015, Rodríguez-Rey, 2016). The BPRS, which is a measurement tool for self-assessment of the individual, is a one-dimensional scale comprising six items. The items in the scale have a 5-point Likert-type rating such as "Not at all appropriate", "Not suitable", "Somewhat suitable", "Suitable" and "Completely suitable", and three items of the scale are coded in reverse. High scores on the BPRS show high psychological resilience.

Turkish adaptation of the scale was carried out by Doğan (2015). Because of the exploratory factor analysis performed for construct validity, it was determined that the factor loadings of the items varied between .63 and .79 , and a single factor structure was got that explained $54 \%$ of the total variance. With the confirmatory factor analysis, the fit of the model was examined with many different goodness-of-fit indexes, and this structure was confirmed. The reliability coefficient of the BPRS got by the internal consistency method was found to be .83 .

As a result, results consistent with the original scale were got in the validity and reliability study.

The next criterion was that the findings of the studies examined included a comparison in terms of gender differences. In this respect, studies were examined in terms of the number of people in gender groups, the BPRS mean scores for each group, and whether their standard deviations were reported. 30 studies, 13 theses, 
and 17 articles meeting these criteria were included in the research.

\section{Coded Properties of Studies}

The differences between the results of individual studies in meta-analysis studies may be caused by different variables addressed in the studies. For this reason, systematic coding was used to understand the characteristics of primary studies and to investigate and define study characteristics that could be potential moderators for inconsistent findings of individual studies. Some study features in this coding form are: (1) study number, (2) authors, (3) year of publication, (4) type of publication, (5) study group (6) data collection method, (7) a total number of participants, 8) the number of women participants, (9) the number of men participants, (10) the mean scores of the BPRS for women, (11) the standard deviation of the mean scores of BPRS for women, (12) the mean scores of the BPRS for men, (13) the standard deviation of the mean score of the BRSP for men., (14) t value, (15) p value.

\section{Coding Process and Coding Quality}

Studies of the coding process was carried out by the authors of this article. It can be said that the process comprises three stages. First, a pre-coding plan was created by discussing it among the researchers. In the second step, the two versions of the encoding performed by the researchers independently were compared. He discussed the differences between the encoding. Finally, all studies were carefully coded again by the two coders, and a complete agreement was reached between them.

\section{Data Analysis}

A meta-analysis was conducted out of 30 studies included in this study. The data of the study were analyzed using the meta-package (Schwarzer, 2007) over the R 4.0.0 program.

Before proceeding to the main analysis of the study, it was checked whether there was publication bias. Publication bias may occur because of the higher probability of publication of studies with large samples or studies with statistically significant results. This may lead to an overestimation of the mean effect size (Borenstein, 2009). Therefore, before calculating the values for effect sizes, it is necessary to examine the studies included in the analysis in terms of publication bias. In this study, funnel plot and Egger's linear regression test (Egger, 1997) were used to test the publication bias. In the funnel plot approach, the vertical axis represents the standard error of the studies and the horizontal axis represents the effect size. Each point in the chart shows the studies included in the analysis. The symmetry of this graph is examined for publication bias (Duval \& Tweedie, 2000). The symmetrical distribution of the studies around the vertical line, which has the general effect, provides evidence that there is no publication bias in the study (Egger, 1997). The funnel plot got to test the publication bias is given in Figure 1.

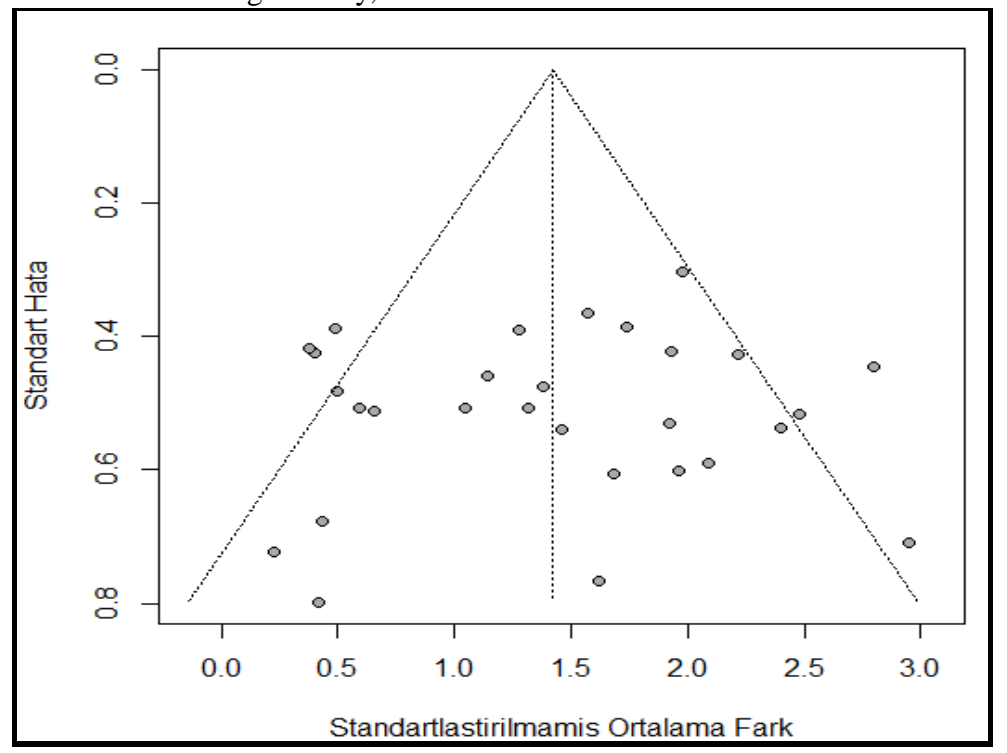

Figure 1. Funnel Plot Regarding the Effect of the Gender Variable on Psychological Resilience Level

When Figure 1 is examined, it is seen that the effect size of 30 studies included in the study is balanced on the right and left of the vertical line. When the graphic is tested, it can be said that there is not enough evidence for publication bias in the study, since most of the studies are in a funnel shape and symmetrical. However, it does not decide on publication bias visually and should be supported by statistical findings. For this reason, Egger test was carried out to test the symmetry of the funnel plot. Because of this test, it was determined that $t(28)=$ $.367, p=0.72(p>.05)$, and considering this result, it can be said that there is a symmetrical distribution in the funnel plot.
At the first stage of the analysis, effect sizes for each study were calculated. There are two models in the metaanalysis, random effects and fixed effect models. However, in this study, in line with the suggestion of using the random effects model in social sciences (Field $\&$ Gillett, 2010), the analyzes were carried out through the random effects model. The non-standardized mean difference the measure of effect size. Because the measurement tool used in studies included in the metaanalysis is the same. In such cases, a meta-analysis is performed by directly calculating the raw differences of the tools to determine the effect size (Çoğaltay \& Karadağ, 2015). 
The effect size for this study was calculated using a formula based on the difference between mean scores for men and mean scores for women. Therefore, the positive effect size shows that men have a higher psychological resilience level than women. Effect size is interpreted as low for .20 and below, medium for $.20-.80$, broad for .80 and above (Cohen, 1988). For each study, a weighted mean effect size was estimated at a $95 \%$ confidence interval and a forest chart was created. Then the heterogeneity test examinations were passed. For this purpose, Cochrane's Q statistics and $\mathrm{I}^{2}$ index, which are widely used, were used to test the importance of unexplained heterogeneity. Cochran's Q statistics are used to test the heterogeneity between effect sizes got from individual studies and provide information about the presence or absence of heterogeneity (Huedo-Medina, 2006). The significance of the $Q$ statistics shows that the moderator variables should be tested (Borenstein et al., 2009; Lipsey \& Wilson, 2001). The $\mathrm{I}^{2}$ index used to estimate the observed variance ratio not caused by sampling error can express the level of heterogeneity. $\mathrm{I}^{2}$ values of $25 \%, 50 \%$, and $75 \%$ show low, medium, and high heterogeneity, respectively (Higgins, 2003).Third, moderator analyzes were conducted to investigate factors that may cause heterogeneity between studies. The moderator variables used in this study are the type of publication (article, thesis), study group (university, high school, employee, other), the way the data are collected (online, paper-pencil, mixed), and the total number of participants $(100-200,201-300,301-400,401-500,500$ and above).

\section{Findings}

The 30 selected studies included 11,140 participants ( $57 \%$ women, $43 \%$ men). The effect size got because of considering the PR levels of individuals in terms of gender differences, the lower and upper limits of this effect size according to the $95 \%$ confidence interval, the $t$ and $p$ values, and the findings regarding the heterogeneity test are given in Table 1 .

Table 1.

Effect Size and Heterogeneity Test Findings According to Random Effects Model

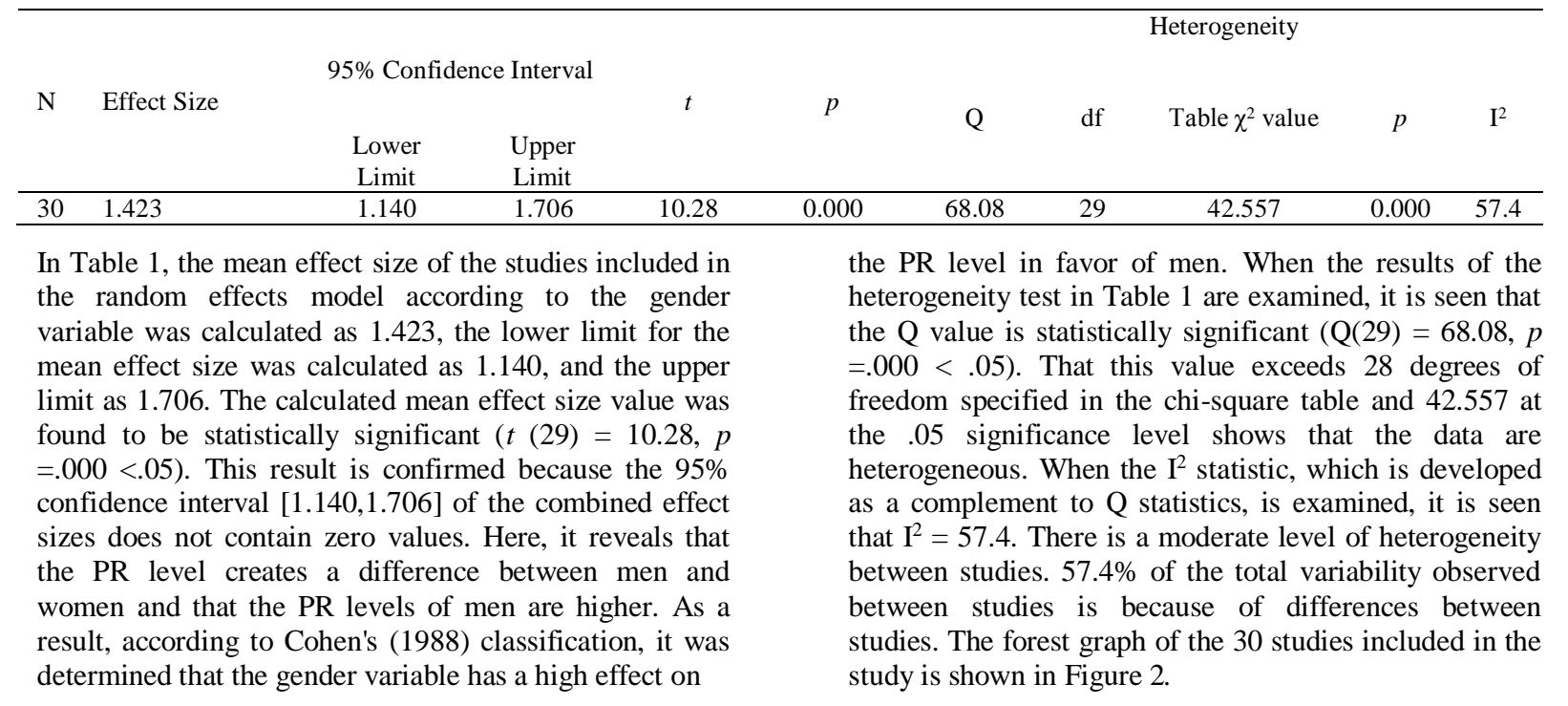
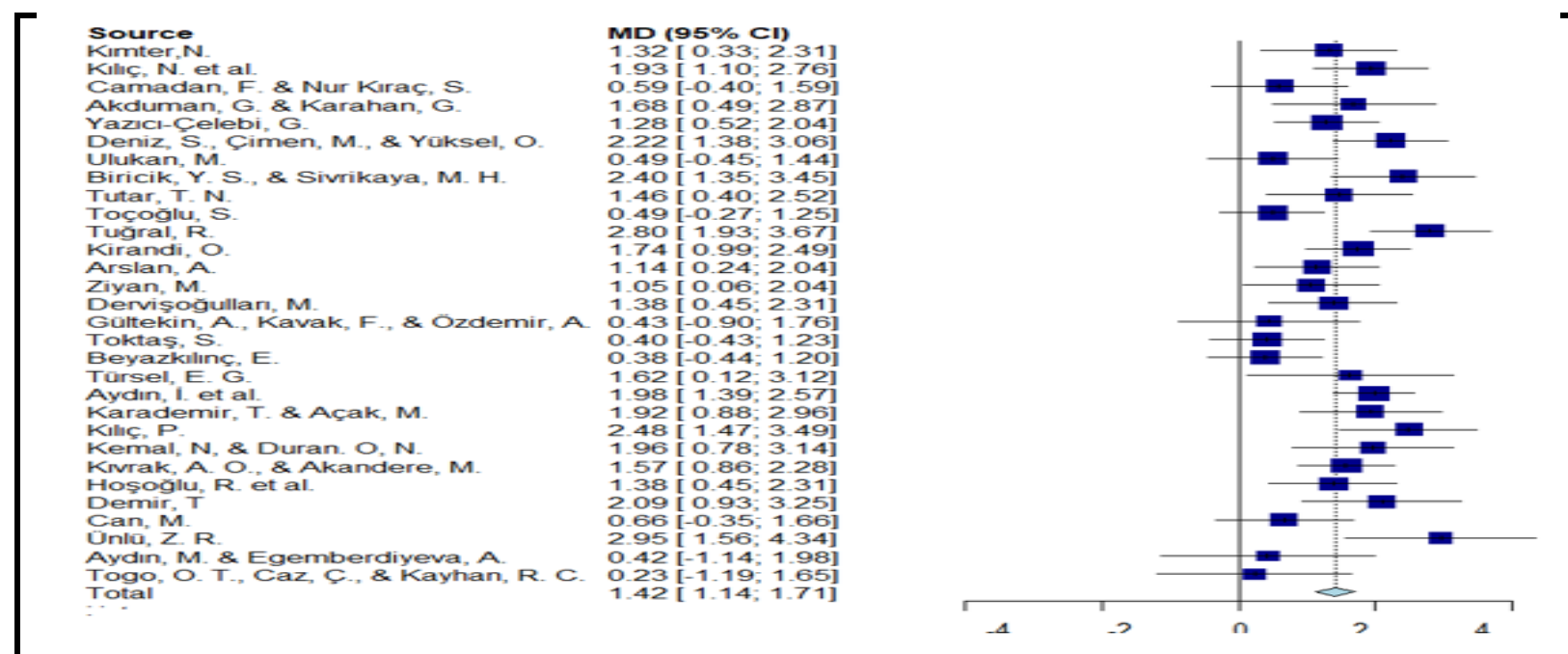

Figure 2. Forest Chart of the Studies 
In Figure 2, the effect size of each study is shown with the square shape and the $95 \%$ confidence intervals for the effect size of the studies, with the lines extending from both sides of these squares.

The diamond shape at the end of the figure expresses an estimate of the overall effect size. The effect sizes calculated according to the gender differences of the PR of individuals vary between .23 and 2.95 .

In these studies, the result is in favor of men. However, these differences were significant in 20 studies and insignificant in 10 studies. The lower limit of the effect sizes of these studies with 10.803 participants varies between -1.19 and 1.93 and the upper limit varies between 1.20 and 4.34 .

\section{Table 2.}

Findings Regarding the Moderator Analysis

\section{Moderator analyzes}

Because of heterogeneity tests $\left(\mathrm{Q}\right.$ and $\left.\mathrm{I}^{2}\right)$, there was a moderate level of heterogeneity between studies, so the plausible reasons for this heterogeneity were tried to be revealed. For this purpose, moderator analysis was conducted over some variables selected at the beginning of the study. In the research, the type of publication (article, thesis), study group (university, high school, employee, other), the way the data were collected (online, paper-pencil, mixed), and the total number of participants (100-200, 201-300, 301-400, 401-500, 500 and above) variables are moderator variables. Table 2 presents the findings that moderator variables do not play a role in the differences in psychological resilience levels of individuals based on gender groups.

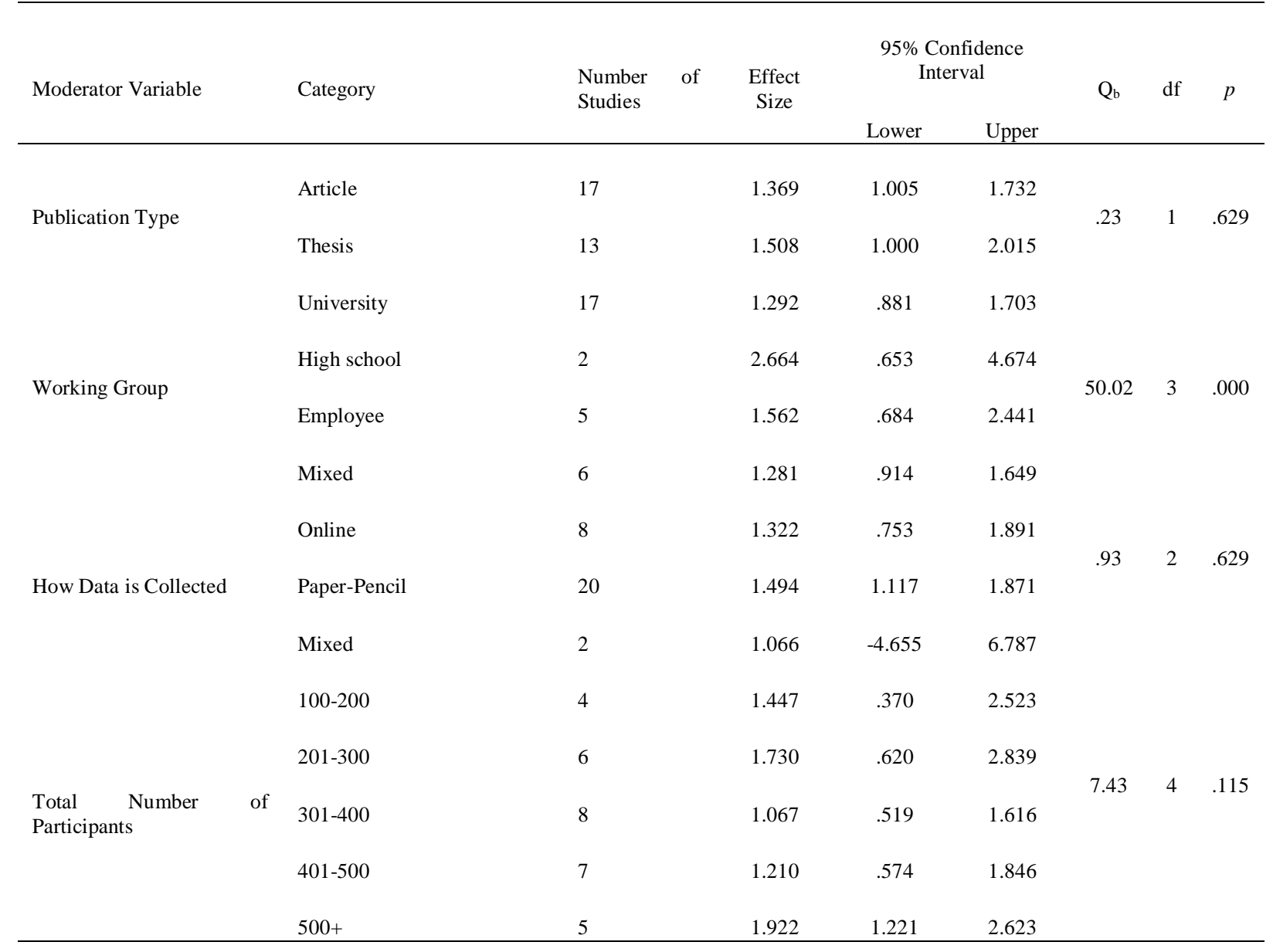

When the findings regarding the publication type variable, which is the first moderator variable in Table 2 , are examined, it is seen that the mean effect size for the articles is $1.369,95 \% \mathrm{CI}[1.005,1.732]$ and the mean effect size for the theses is $1.508,95 \%$ CI [1.000, 2.015]. This result shows that the PR levels of studies from both types of publications are higher in favor of men. When the significance of the difference between groups based on the publications was taken into consideration with the heterogeneity test, it was concluded that this variable was not a moderator variable that had a significant role in the differentiation of individuals' PR according to the gender variable $\left(\mathrm{Q}_{\mathrm{b}}(1)=.23, p=.629>.05\right)$. Similarly, the $\mathrm{Q}$ values 1 degree of freedom indicated in chi-square table and being smaller than the value of 3.841 in 05 confidence level, indicates that there is no significant difference between groups.

Second, according to the results of the moderator analysis, the mean effect size for university students is $1.292,95 \%$ CI [.881, 1.703], the mean effect size for high school students is $2.664,95 \%$ CI $[.653,4.674]$, and the mean effect size for employees is $1.562,95 \%$ CI [.684, 2.441], it is seen that the mean effect size for the mixed group is $1.281,95 \%$ CI $[.914,1.649]$. When the significance of the difference between the groups formed 
according to the study groups was tested with the heterogeneity test, it was concluded that this variable was a moderator variable that had a significant role in the differentiation based on the gender variable at the level of $\mathrm{PR}\left(\mathrm{Q}_{\mathrm{b}}(3)=50.02, p<.05\right)$. Similarly, the $\mathrm{Q}$ values 3 degree of freedom indicated in chi-square table and being greater than the value of 7.815 in 05 confidence level, indicates that there is significant difference among groups.According to the way the data is collected, the third variable, the mean effect size obtained as a result of collecting data online was calculated as $1.322,95 \%$ CI $[.753,1.891]$; the mean effect size obtained as a result of collecting data paper-pencil test was calculated as 1.494 , $95 \%$ CI $[1.117,2.008]$; the mean effect size obtained as a result of collecting data in both ways was calculated as $1.066,95 \%$ CI $[-4.655 ; 6.787]$. It was found that this variable was not a moderator variable that had a significant role in the differentiation in the PR level of individuals according to the gender variable $(\mathrm{Qb}(2)=.93$, $p=.629>.05)$. Similarly, the $\mathrm{Q}$ values 2 degree of freedom indicated in chi-square table and being smaller than the value of 5.991 in 05 confidence level, indicates that there is no significant difference between groups.

The mean effect size calculated according to the total number of participants, which is the fourth variable, was calculated as $1.447,95 \%$ CI [.370, 2.523] for the 100-200 sample size; $1.730,95 \%$ CI $[620,2.839]$ for the $201-300$ sample size; $1.067,95 \%$ CI $[.519,1.616]$ for the $301-400$ sample size; $1.210,95 \%$ CI [.574, 1.846] for the 401-500 sample size; and $1.922,95 \%$ CI $[1.221,2.623]$ for the 500 and above sample size. It was found that this variable was not a moderator variable that had a significant role in the differentiation in the PR level of individuals according to the gender variable $\left(\mathrm{Qb}_{\mathrm{b}}(4)=7.43, p=.115\right.$ > $.05)$. Similarly, the $\mathrm{Q}$ values 4 degree of freedom indicated in chi-square table and being smaller than the value of 9.488 in 05 confidence level, indicates that there is no significant difference between groups.

\section{Conclusion, Discussion and Suggestions}

This study aims to examine the psychological resilience of individuals in terms of gender differences using the meta-analysis method. For this purpose, the findings of 17 articles and 13 thesis studies by the inclusion criteria of the research were combined. Because of the metaanalysis, it was determined that there was no publication bias.

Analyzes using the random effects model showed that the PR levels of men were higher than the PR levels of women, and this difference was found to be statistically significant. This result differs from the findings of the study conducted by Arı and Çarkit (2020). In a metaanalysis study conducted over 57 theses, the researchers determined that the PR level of the individuals according to the gender variable was higher in favor of women, but this difference was not significant. Although there are beliefs that women are innately vulnerable and in need of protection in terms of gender roles, their accuracy has not been proven. The dominant, ambitious, courageous, etc., are accepted as masculine by society. Individuals who are determined to have more characteristics (Dökmen, 2017) are more competent in doing business, problem-solving, being strong and free (Bem, 1974). Men who make this type of gender typing stay away from behaviors such as crying, expressing problems, and asking for help
(Dökmen, 2017). Avoiding these behaviors may cause them to think that they are sufficient in terms of PR and that they can cope with all kinds of crises.

It was determined that the data of the combined studies differ from each other according to the heterogeneity test results. To investigate the reasons for these differences, the type of publication (article, thesis), study group (university, high school, employee, other), the way the data were collected (online, paper-pencil, mixed), and the total number of participants (100-200, 201-300, 301-400, 401-500, 500 and above) variables were selected as the moderator variable. Because of the moderator analysis, it was determined that only the study group variable among these variables had a significant role in the differentiation of individuals' PR based on the gender variable. The PR level of high school students in the study group was at the highest level, followed by employees, university students, and the mixed group. Since the high school education period also coincides with the adolescence period, it is important to identify and put into practice the factors that increase psychological resilience in these years. Adolescence is regarded as a period in which identity formation is experienced, and there are certain crises in adolescence as in other developmental periods of life (Atkinson, 2020; Bandura, 2006). All these point to the necessity of PR in adolescence. Being able to adapt to both physiological and emotional changes and maintaining mental health despite crises make up the basis of psychological resilience (Lin et al., 2004).

The high level of PR of individuals can be an important advantage not only for mental health but also for working life. Individuals spend a significant part of their time dealing with activities related to their work. During this period, employees may face many stress factors (Chuang $\&$ Lei, 2011). The PR in working life can be one of the positive emotions that can help cope with the negativities encountered, especially to reduce work stress (Cooke, 2019).

University education following adolescence, which is a critical period, exposes the individual to serious developmental and environmental factors (Ercan, 2010). The period of university education also coincides with a turning point between adolescence and adulthood. Changes such as the differentiation of living conditions and adaptation to the work style required by a higher education level can trigger psychological problems in many university students (Bouteyre, 2007). When the literature is examined, it can be said that university students with high psychological resilience will be easier to adapt to university life (Harry \& Coetzee, 2011; Kaba \& Keklik, 2010; Pidgeon \& Keye, 2014; Sürücü \& Bacanl1, 2010).

It is known that the validity of the results got in individual studies with similar findings through metaanalysis can be strengthened (Akgöz, 2004). For this reason, it can be said that the result can strengthen the validity of the results of individual studies with similar findings. There are some limitations and recommendations to be considered in this research. This meta-analysis was published only comprises 30 articles and theses held in Turkey and the years 2018-2019. Therefore, future research can be repeated with the studies of different countries and in a wider time interval. This study is limited to studies that collect data with the Brief Psychological Resilience Scale (BPRS), which is a 
scale that is widely used in 2020 . In the literature, there are also measurement tools that include many and more items that are used to determine the PR levels of individuals.

Considering that the psychometric properties of measurement tools may affect the results, this study was studied in the same unit. Other studies in the literature focus on certain measurement tools in this way for metaanalysis studies (He, 2020; Siddiq \& Scherer, 2019). Again, with a similar study, the situation of the same issue in the world or different countries can be examined and comparison opportunities can be provided. As a complement to this research, screening research can be conducted with qualitative studies on the subject.

Although it was determined that there was heterogeneity among the data of the studies in this study, this situation could not be explained with most of the moderator variables selected. Therefore, studies dealing with The $\mathrm{PR}$ and gender differences can also be examined with different moderator variables. Also, unlike this study, which tests the PR level of individuals only based on gender difference, a different meta-analysis study can be conducted on various variables that are related to psychological resilience.

\section{Declarations}

Ethics Approval and Consent To Participate

For this type of study formal consent is not required.

\section{Consent For Publication}

Not applicable.

\section{Availability of Data and Materials}

The data that support the findings of this study are available on request from the corresponding author.

\section{Conflict of Interest}

The authors declare no conflict of interest.

\section{Funding}

The author(s) received no financial support for the research, authorship, and/or publication of this article.

\section{Authors' Contribution}

EYK and AG designed the study. EYK designed data collection procedure, monitored data collection, wrote the statistical analysis plan, cleaned and analysed the data, and drafted and revised the paper. AG created the theoretical framework, monitored data collection, and revised the draft paper. Both authors read and approved the final manuscript.

\section{Acknowledgments}

No acknowledgements was needed to declare.

\section{References}

Akduman, G., \& Karahan, G. (2020). Kabin memurunun sahip olması gereken yetkinlikler: sivil havacılık kabin hizmetleri mezunu istihdam edilen kişilerle bir alan araştırması. Havacllık ve Uzay Çalı̧smaları Dergisi, 1(1), 7-32.

Akgöz, S., Ercan, İ., \& Kan, İ. (2004). Meta analysis. Journal of Uludağ University Faculty of Medicine, 30(2), 107-112.

Arı, F. A., \& Çarkıt, E. (2020). Investigation of resilience in terms of gender: A meta-analysis study. Research on Education and Psychology (REP), 4(Special Issue), 34-52. http://dergipark.org.tr/rep

Arslan, A. (2020). Beliren yetişkinlik dönemindeki bireylerin yakın ilişsi şiddeti algularının baş etme stilleri ve psikolojik sağlamlı düzeyleri arasındaki ilişkinin incelenmesi (Yayınlanmamış yüksek lisans tezi). Kocaeli Üniversitesi Eğitim Bilimleri Enstitüsü.

Artan, T., Atak, I., Karaman, M., \& Cebeci, F. (2020). The relationship between sociodemographic characteristics, psychological resilience and anxiety levels in the coronavirus (COVID-19) outbreak. Electronic Turkish Studies, 15(6), 79-94.

Atkinson, R. L., Atkinson, R. C., Smith, E. E., Bem, D. J., \& Nolen-Hoeksema, S. (2010). Introduction to Psychology. (Yavuz Alogan, Trans.). Friend Publishing.

Aydın, İ., Erman, Ö., Akbulut, V., \& Kılıç, S. K. (2019). Öğretmen adaylarında boş zaman sikılma algısı ve psikolojik sağlamlık ilişkisi. Beden Eğitimi ve Spor Bilimleri Dergisi, 21(1), 39-53.

Aydın, M., \& Egemberdiyeva, A. (2018). Üniversite ögrencilerinin psikolojik sağlamlı düzeylerinin incelenmesi. Türkiye Eğitim Dergisi, 3(1), 37-53.

Aydoğdu, T. (2015). Investigation of the relationship between attachment styles, coping strategies and psychological resilience (Unpublished Master's Thesis). Gazi University.

Bandura, A. (2006). Adolescent development from an agentic perspective. Selfefficacy Beliefs of Adolescents, 5, 1-43.

Bem, S. L. (1974). The measurement of psychological androgyny. Journal of Consulting and Clinical Psychology, 42(1), 155- 162.
Beyazkılınç, E. (2019). Yüksek din öğretimi öğrencilerinde Allah'a bağlanma ve psikolojik sağlamllk: Ankara Üniversitesi Ilahiyat Fakültesi örneği (Yayımlanmamış yüksek lisans tezi). Ankara Üniversitesi.

Bilge, Y. \& Bilge, Y. (2020). Examining the effects of the coronavirus epidemic and social isolation on psychological symptoms in terms of psychological resilience and coping styles. Journal of Clinical Psychiatry, 23(1), 38-51.

Biricik, Y. S., \& Sivrikaya, M. H. (2020). Investigation of psychological resilience and self-effect levels of faculty of sports students. International Journal of Applied Exercise Physiology, 9(9), 82-89.

Borenstein, M., Hedges, L. V., Higgins, J. P. T., \& Rothstein, H. R. (2009). Introduction to meta-analysis. Wiley.

Bouteyre, E., Maurel, M., \& Bernaud, J. L. (2007). Daily hassles and depressive symptoms among first year psychology students in France: The role of coping and social support. Stress and Health: Journal of the International Society for the Investigation of Stress, 23(2), 93-99.

Bozdağ, F. (2020). Psychological resilience during the pandemic. Turkish Studies, 15(6), 247-257.

Bozgeyikli, H. (2017). Big five personality traits as the predictor of teachers' organizational psychological capital. Journal of Education and Practice, 8(18), 125-135.

Bradley, R. H., Whiteside, L. Munford, D. J., Casey, P. H., Kelleher, K. J., \& Pope, S. K. (1994). Early indications of resilience and their relation to experiences in the home environments of low birthweight, premature children living in poverty. Child Development, 65(2), 346-360.

Camadan, F., \& Kıraç, S. N. (2020). Examining self-esteem and various demographic variables as a predictor of university students' psychological resilience. Journal of Higher Education and Science, 10(2), 253-263.

Campbell-Sills, L., Forde, D. R., \& Stein, M. B. (2009). Demographic and childhood environmental predictors of resilience in a community sample. Journal of Psychiatric Research, 43, 1007-1012. 
Can, M. (2018). Üniversite öğrencilerinin mutluluk, psikolojik sağlamllk ve öz yeterlik düzeylerinin incelenmesi (Yayımlanmamış yüksek lisans tezi). İstanbul Aydın Üniversitesi Sosyal Bilimler Enstitüsü, İstanbul.

Carriedo, A., Cecchini, J. A., Fernandez-Rio, J., \& MéndezGiménez, A. (2020). COVID-19, psychological well-being and physical activity levels in older adults during the nationwide lockdown in Spain. The American Journal of Geriatric Psychiatry, 28(11), 1146-1155.

Chuang, N.K. ve Lei, S.A. (2011). Job stress among casino hotel chefs in a top-tier tourism city. Journal of Hospitality Marketing \& Management, 20(5), 551-574.

Cicchetti, D., \& Rogosch, F. A. (2007). Personality, adrenal steroid hormones, and resilience in maltreated children: A multilevel perspective. Development and Psychopathology, 19(3), 787-809. https://doi.org/10.1017/S0954579407000399.

Cohen, J. (1988). Statistical power analysis for the behavioral sciences (2nd edition). New York: Routledge.

Cooke, F.L., Wang, J., \& Bartram, T. (2019). Can a supportive workplace impact employee resilience in a high pressure performance environment? An investigation of the Chinese banking industry. Applied Psychology: An International Review, 68(4), 695-718. https://doi.org/10.1111/apps.12184

Cumming, G. (2013). Understanding the new statistics: Effect sizes, confidence intervals, and meta-analysis. New York: Routledge.

Çelebi, G. Y. (2020). Covid 19 salgınına ilişsin tepkilerin psikolojik sağlamlık açısından incelenmesi. IBAD Sosyal Bilimler Dergisi, (8), 471-483. DOI: 10.21733/ibad.737406

Coğaltay N. \& Karadağ, E. (2015). Introduction to metaanalysis. In E. Karadağ (Ed.), Leadership and organizational outcomes: Meta-analysis of empirical studies, (pp.19-28). Springer

Davidson, J. R. T., Payne, V. M., Connor, K. M., Foa, E. B., Rothbaum, B. O., Hertzberg, M. A., \& Weisler, R. H. (2005). Trauma, resilience and saliostasis: Effects of treatment in posttraumatic stress disorder. International Clinical Psychopharmacology, 20, 43-48. https://doi.org/10.1097/00004850-200501000-00009

de Holanda Coelho, G. L., Hanel, P. H., Medeiros Cavalcanti, T., Teixeira Rezende, A., \& Veloso Gouveia, V. (2016). Brief Resilience Scale: Testing its factorial structure and invariance in Brazil. Universitas $\quad$ Psychologica, 15(2), 397-408. https://doi.org/10.11144/Javeriana.upsyl5-2.brst

Demir, T. (2018). Sağlık çalışanlarında algılanan stres, psikolojik sağlamlık ve bilisssel duygu düzenleme stratejilerinin durumluk ve sürekli kaygl düzeyini yordama gücü (Yayımlanmamış yüksek lisans tezi). İstanbul Arel Üniversitesi, Sosyal Bilimler Enstitüsü, İstanbul.

Deniz, S., Çimen, M., \& Yüksel, O. (2020). Psikolojik sağlamlığın iş stresine etkisi: hastane çalışanlarına yönelik bir araştırma. İşletme Bilimi Dergisi, 8(2), 351-370.

Dervişoğulları, M. (2020). Eğitim fakültesi öğretim elemanlarının psikolojik sağlamlıkları, akademik erteleme eğilimleri, işle ilgili akışları ve mesleki yeterlikleri arasındaki ilișilerin incelenmesi (Yayımlanmamıs doktora tezi). Marmara Üniversitesi, Eğitim Bilimleri Enstitüsü.

Doğan, T. (2015). Turkish adaptation of the short psychological resilience scale: Validity and reliability study. The Journal of Happiness \& Well-Being, 3(1), 93-102.

Dökmen, Z. Y. (2017). Toplumsal cinsiyet - sosyal psikolojik açıklamalar [Social gender, social psychological explanations]. Ankara: Remzi Kitabevi.
Duval, S., \& Tweedie, R. (2000). Trim and fill: A simple funnelplot-based method of testing and adjusting for publication bias in meta-analysis. Biometrics, 56(2), 455-463.

Egger, M., \& Smith, G. D. (1997). Meta-analysis: Potentials and promise. British Medical Journal, 315(7119), 1371-1374. https://doi.org/10.1136/bmj.315.7119.1371

Egger, M., Smith, G. D., Schneider, M., \& Minder, C. (1997). Bias in meta-analysis detected by a simple, graphical test. British Medical Journal, 315(7109), 629-634.

Ercan, L. E. (2010). An analysis of the relationship between attitudes towards seeking psychological help and problem solving among university students. Procedia-Social and Behavioral Sciences, 2(2), 1814-1819.

Eryllmaz, S. (2012). Investigation of life satisfaction, selfesteem, optimism and locus of control in predicting psychological resilience in university students (Unpublished Master's Thesis). Mugla University.

Feng, F., Ming, L. I., Ruofan, L. I., Bingzhang, L. I., \& Cao, C. (2016). Mediating effects of self feeling of inadequacy between resilience and alexithymia in depressive undergraduates. Chinese Journal of Behavioral Medicine and Brain Science, 25(1), 7075. https://doi.org/10.1111/jan.14208

Ferguson, C. J., \& Brannick, M. T. (2012). Publication bias in psychological science: Prevalence, methods for identifying and controlling, and implications for theuse of meta-analyses. Psychological Methods, 17, 120-128.

Field, A. P., \& Gillett, R. (2010). How to do a metaanalysis. British Journal of Mathematical and Statistical Psychology, 63(3), 665-694.

Fung, S. F. (2020). Validity of the brief resilience scale and brief resilient coping scale in a Chinese sample. International Journal of Environmental Research and Public Health, 17(4), 1265. https://doi.org/10.3390/ijerph17041265

Gizir, C. (2007). A review study on psychological resilience, risk factors and protective factors. Turkish Journal of Psychological Counseling and Guidance, 3(28), 113-128. https://dergipark.org.tr/en/download/article-file/200204

Glass, G. V. (1976). Primary, secondary, and meta-analysis of research. Educational Researcher, 5(10), 3-8.

Gultekin, A., Kavak, F., \& Ozdemir, A. (2019). The correlation between spiritual well-being and psychological resilience in patients with liver transplant. Medicine, 8(3), 531-536.

Harry, N., \& Coetzee, M. (2011). Sense of coherence, affective wellbeing and burnout in a South African higher education institution call centre. South African Journal of Labour Relations, 35(2), 26-46. http://hdl.handle.net/10500/5549

He, J., Sun, S., Zickgraf, H. F., Lin, Z., \& Fan, X. (2020). Metaanalysis of gender differences in body appreciation. Body Image, 33, 90-100

He, Z., Chen, J., Pan, K., Yue, Y., Cheung, T., Yuan, Y., ... \& Zhou, Y. (2020). The development of the'COVID-19 Psychological Resilience Model'and its efficacy during the COVID-19 pandemic in China. International Journal of Biological Sciences, 16(15), 2828-2834.

Higgins, J. P., Thompson, S. G., Deeks, J. J., \& Altman, D. G. (2003). Measuring inconsistency in meta-analyses. BMJ, 327(7414), 557-560. https://doi.org/10.1136/bmj.327.7414.557

Hirani, S., Lasiuk, G., \& Hegadoren, K. (2016). The intersection of gender and resilience. Journal of Psychiatric and Mental Health Nursing, 23(6-7), 455-467. 
Hoşoğlu, R., Kodaz, A. F., Bingöl, T. Y., \& Batık, M. V. (2018). Öğretmen adaylarında psikolojik sağlamlık. OPUS Uluslararası Toplum Araştırmaları Dergisi, 8(14), 217-239.

Huedo-Medina, T. B., Sánchez-Meca, J., Marín-Martínez, F., \& Botella, J. (2006). Assessing heterogeneity in meta-analysis: Q statistic or $\mathrm{I}^{2}$ index? Psychological Methods, 11, 193-206. https://doi.org/10.1037/1082-989X

Joanna Briggs Institute (2018). Critical appraisal tools. http://joannabriggs.org/research/critical-appraisal-tools.html

Joseph, S., \& Linley, P. A. (2006). Growth following adversity: Theoretical perspectives and implications for clinical practice. Clinical Psychology Review, 26(8), 1041-1053. https://doi.org/10.1016/j.cpr.2005.12.006

Joyce, S., Shand, F., Tighe, J., Laurent, S. J., Bryant, R. A., \& Harvey, S. B. (2018). Road to resilience: a systematic review and meta-analysis of resilience training programmes and interventions. BMJ Open, 8(6), 1-9.

Kaba, İ., \& Keklik, İ. (2016). Psychological resilience and psychological symptoms in students' adaptation to university life. Hacettepe University Institute of Educational Sciences Journal of Educational Research, 2(2), 458-777. https://dergipark.org.tr/tr/pub/huner/issue/36362/411244

Kang, L., Li, Y., Hu, S., Chen, M., Yang, C., Yang, B. X., ... \& Chen, J. (2020). The mental health of medical workers in Wuhan, China dealing with the 2019 novel coronavirus. The Lancet Psychiatry, 7(3), 14. https://doi.org/10.1016/S22150366(20)30047-X

Karademir, T., \& Mahmut, A. (2019). Üniversiteli sporcuların psikolojik dayanıklılıd düzeylerinin incelenmesi. Kahramanmaraş Sütçü Imam Üniversitesi Sosyal Bilimler Dergisi, 16(2), 803-816.

Karairmak, Ö. (2006). Psychological resilience, risk factors and protective factors. Turkish Journal of Psychological Counseling and Guidance, 3(26), 129-142.

Karaşar, B., \& Canlı, D. (2020). Psychological resilience and depression during the Covid-19 pandemic in Turkey. Psychiatria Danubina, 32(2), 273-279.

Kasapoğlu, F. (2020). Examining the relationships between anxiety and spirituality, psychological resilience and intolerance to uncertainty during the COVID-19 pandemic. Electronic Turkish Studies, 15(4), 599-614.

Kemal, N., \& Duran, N. O. (2019). Türkiye'de yükseköğretimdeki Ahıskalı öğrencilerin mutluluk ve psikolojik sağlamlık düzeylerinin bazı demografik değişkenler açısından incelenmesi. Maarif Mektepleri Uluslararası Sosyal ve Beşeri Bilimler Dergisi, 3(1), 1-15.

Kılıç, N., Mammadov, M., Koçhan, K., \& Aypay, A. Üniversite öğrencilerinde genel öz yeterlik inancı ve beden imajının psikolojik sağlamlık düzeyini yordama gücü. Hacettepe Üniversitesi Ĕgitim Fakültesi Dergisi, 35(4), 904-914.

Kılıç, P. (2019). Ergenlerde beden imgesi ile psikolojik sağlamlık ve mutluluk düzeyleri arasındaki ilișki (Yayımlanmamış yüksek lisans tezi). Yıldız Teknik Üniversitesi, İstanbul.

Kıvrak, A. O., \& Akandere, M. (2019). Examination of the resilience levels of women and men do sport in gyms. Türk Spor ve Egzersiz Dergisi, 21(2), 223-228.

Kimhi, S., Marciano, H., Eshel, Y., \& Adini, B. (2020). Resilience and demographic characteristics predicting distress during the COVID-19 crisis. Social Science \& Medicine, 265, 1 6. https://doi.org/10.1016/j.socscimed.2020.113389

Kimter, N. (2020). Covid-19 günlerinde bireylerin psikolojik sağlamlık düzeylerinin bazı değişkenler açısından incelenmesi. IBAD Sosyal Bilimler Dergisi, (Özel Sayl), 574-605.
Kirandi, O. (2020).Beden eğitimi öğretmeni adaylarında psikolojik sağlamlık ve serbest zaman sıkılma algısı ilişkisi (Yayınlanmamış yüksek lisans tezi). Trabzon Üniversitesilisansüstü Eğitim Enstitüsü.

Kobasa, S. C. (1979). Stressful life events, personality, and health: An inquiry into hardiness. Journal of Personality and Social Psychology, 37(1), 1-11.

Konaszewski, K., Niesiobędzka, M., \& Surzykiewicz, J. (2020). Validation of the Polish version of the Brief Resilience Scale (BRS). PloS One, 15(8), e0237038. https://doi.org/10.1371/journal.pone.0237038

Kul, A., Demir, R., \& Katmer, A. N. (2020). Life meaning and anxiety as predictors of psychological resilience during the Covid-19 outbreak. Electronic Turkish Studies, 15(6), 695-719. https://dx.doi.org/10.7827/TurkishStudies.44419

Kumpfer, K. L. (1999). Factors and processes contributing to resilience: the resilience framework. In M. D. Glantz and J. L. Johnson (Eds.), Resilience and development: Positive life adaptations. Kluwer Academic/Plenum Publishers.

Lee, J. H., Nam, S. K., Kim, A. R., Kim, B., Lee, M. Y., \& Lee, S. M. (2013). Resilience: a meta- analytic approach. Journal of Counseling \& Development, 91(3), 269-279. https://doi.org/10.1002/j.1556-6676.2013.00095.x

Lee, E. O., Shen, C., \& Tran, T. V. (2008). Coping with hurricane Katrina: Psychological distress and resilience among African American evacuees. Journal of Black Psychology, 20(5), 1-19. http://dx.doi.org/10.1177/0095798408323354

Lin, K. K., Sandler, I. N., Ayers, T. S., Wolchik, S. A., \& Luecken, L. J. (2004). Resilience in parentally bereaved children and adolescents seeking preventive services. Journal of Clinical Child and Adolescent Psychology, 33(4), 673-683. https://doi.org/10.1207/s15374424jccp3304_3

Lipsey, M. W. \& Wilson, D. (2001). Practical meta-analysis. Thousand Oaks, CA: Sage Publications.

Lissoni, B., Del Negro, S., Brioschi, P., Casella, G., Fontana, I., Bruni, C., \& Lamiani, G. (2020). Promoting resilience in the acute phase of the COVID-19 pandemic: Psychological interventions for intensive care unit (ICU) clinicians and family members. Psychological Trauma: Theory, Research, Practice, and Policy, 12, 105-107. http://dx.doi.org/10.1037/tra0000802

Liu, V. Y. Y., \& Lim, S. M. (2020). A psychometric evaluation of the brief resilience scale among tertiary students in Singapore. Asia Pacific Journal of Education, 1-14. https://doi.org/10.1080/02188791.2020.1845120

Littel, H. J., Corcoran, J., \& Pillai, V. (2008). Systematic reviews and meta-analysis. Oxford University Press.

Luthar, S. S., Cicchetti, D., \& Becker, B. (2000). The construct of resilience: A critical evaluation and guidelines for future work. Child Development, 71(3), 543-562.

Luthar, S. S., \& Cicchetti, D. (2000). The construct of resilience: Implications for interventions and social policies. Development and Psychopathology, 12(4), 857-885.

Macovei, C. M. (2015). The Brief Resilience Scale-a Romanianlanguage adaptation. Agora Psycho-Pragmatica,9(1), 70-87. https://www.uav.ro/jour/index.php/app/article/view/473/523

Mandleco, B. L. (2000). An organizational framework for conceptualizing resilience in children. Journal of Child and Adolescent Psychiatric Nursing, 13(3), 99-112. https://doi.org/10.1111/j.1744-6171.2000.tb00086.x

Masten, A. S., Hubbard, J. J., Gest, S. D., Tellegen, A., Garmezy, N., \& Ramirez, M. (1999). Competence in the context of adversity: Pathways to resilience and maladaptation from childhood to late adolescence. Development and Psychopathology, 11, 143-169. 
Masten, A. S. (1994). Resilience in individual development: Successful adaptation despite risk and adversity. In M.C. Wang \& E.W. (Eds.), Educational resilience in inner-city America: Challenges and prospects. Lawrance Erlbaum.

Masten, A. S. (2001). Ordinary magic: Resilience processes in development. American Psychologist, 56(3), 227-238. https://psycnet.apa.org/doi/10.1037/0003-066X.56.3.227

McGloin, J. M., \& Widom, C. S. (2001). Resilience among abused and neglected children grown up. Development and Psychopathology, 13, 1021-1038.

Norris, F. H., Stevens, S. P., Pfefferbaum, B., Wyche, K. F., \& Pfefferbaum, R. L. (2008). Community resilience as a metaphor, theory, set of capacities, and strategy for disaster readiness. American Journal of Community Ppsychology, 41(12), 127-150. https://doi.org/10.1007/s10464-007-9156-6

Oktan, V. (2008). Examination of the psychological resilience of adolescents preparing for the university exam according to various variables (Unpublished Doctorate Thesis). Karadeniz Technical University, Institute of Social Sciences.

Oshio, A., Taku, K., Hirano, M., \& Saeed, G. (2018). Resilience and Big Five personality traits: A meta-analysis. Personality and Individual Differences, 127, 54-60. https://doi.org/10.1016/j.paid.2018.01.048

Öğmiş, S. (2001). Resilience as a personality trait. I. National Child and Crime Symposium: Causes and Prevention Studies, Ankara (29-30 March).

Öz, F., \& Yilmaz, E. B. (2009). An important concept in maintaining mental health: psychological resilience. Hacettepe University Nursing Faculty Journal, 16 (3), 82-89. https://dergipark.org.tr/tr/pub/hunhemsire/issue/7841/103278

Petzold, M. B., Bendau, A., Plag, J., Pyrkosch, L., Mascarell Maricic, L., Betzler, F. \& Ströhle, A. (2020). Risk, resilience, psychological distress, and anxiety at the beginning of the COVID- 19 pandemic in Germany. Brain and Behavior, 10(9), 1-10. https://doi.org/10.1002/brb3.1745.

Pidgeon, A., \& Keye, M. (2014). Relationship between resilience, mindfulness, and pyschological well-being in University students. International Journal of Liberal Arts and Social Science, 2(5), 27-32.

Ramirez, E. R. (2007). Resilience: A concept analysis. Nursing Forum,42, 73-82.

Ran, L., Wang, W., Ai, M., Kong, Y., Chen, J., \& Kuang, L. (2020). Psychological resilience, depression, anxiety, and somatization symptoms in response to COVID-19: A study of the general population in China at the peak of its epidemic. Social Science \& Medicine, 262, 1-6. 113261. https://doi.org/10.1016/j.socscimed.2020.113261

Rew, L., Taylor-Seehafer, M., Thomas, N. Y., \& Yockey, R. D. (2001). Correlates of resilience in homeless adolescents. Journal of Nursing Scholarship, 33(1), 33-40.

Schwarzer, G. (2007). "meta: An R package for metaanalysis." R News 7(3), 40-45.

Siddiq, F., \& Scherer, R. (2019). Is there a gender gap? A metaanalysis of the gender differences in students' ICT literacy. Educational Research Review, 27, 205-217. https://doi.org/10.1016/j.edurev.2019.03.007

State University of New York - Institute for Disaster Mental Health (SUNY-IDMH). (2020). COVID-19: Managing stress in this anxious time.

Stein, M. B., Campbell-Sills, L., \& Gelernter, J. (2009). Genetic variation in 5HTTLPR is associated with emotional resilience. American Journal of Medical Genetics Part B: Neuropsychiatric Genetics, 150B, 900-906. https://doi.org/10.1002/ajmg.b.30916
Sürücü, M., \& Bacanl1, F. (2010). Examination of adherence to university according to psychological resilience and demographic variables. Gazi University Journal of Gazi Educational Faculty, 30 (2) .375-396.

Terzi, Ş. (2005). Resilience model of subjective well-being (Published Doctoral Thesis). Gazi University: Ankara.

Togo, O. T., Caz, C., \& Kayhan, R. F. (2018). The Relationship between resilience and constant hope in students studying sports science. European Journal of Educational Research, 7(3), 583589.

Toktas, S. (2019). Examining the Levels of Forgiveness and Psychological Resilience of Teacher Candidates. Journal of Education and Training Studies, 7(4), 241-249.

Tuğral, R. (2020). Ergenlerde yalnızlık, psikolojik sağlamlık, alglanan sosyal destek ve sosyal görünüş kaygısı (Yayımlanmamış yüksek lisans tezi). Nişantaşı Üniversitesi Sosyal Bilimler Enstitüsü.

Tutar, T. N. (2020). Üniversite öğrencilerinin bilişsel değerlendirme ve duygu düzenlemeleri ile psikolojik sağlamlıkları arasındaki ilişkilerin incelenmesi (Yayımlanmamıș yüksek lisans tezi). Dokuz Eylül Üniversitesi, Eğitim Bilimleri Enstitüsü.

Türsel, E. G. (2019). İkili ABCX stres modeli kapsamında bir inceleme: Yaygın gelişimsel bozukluk tanılı çocukların ebeveynlerinin aile иуити ve duygu sosyalleștirme tepkileri (Yayımlanmamış yüksek lisans tezi). Bursa Uludağ Üniversitesi.

Ulukan, M. (2020). Öğretmenlerin mutluluk ile psikolojik sağlamlık düzeyleri arasındaki ilişkinin incelenmesi. Journal of International Social Research, 13(73), 620-631.

Ünlü, Z. R. (2018). Sosyal medya bağımlılı̆̆l ve psikolojik dayanıklılık (Yayımlanmamış yüksek lisans tezi). Üsküdar Üniversitesi, Sosyal Bilimler Enstitüsü, İstanbul.

Yildirım, M., \& Arslan, G. (2020). Exploring the associations between resilience, dispositional hope, preventive behaviours, subjective well-being, and psychological health among adults during early stage of COVID-19. Current Psychology, 1-11. https://doi.org/10.1007/s12144-020-01177-2

Zhang, M., Zhang, J., Zhang, F., Zhang, L., \& Feng, D. (2018). Prevalence of psychological distress and the effects of resilience and perceived social support among Chinese college students: Does gender make a difference?. Psychiatry Research, 267, 409413. https://doi.org/10.1016/j.psychres.2018.06.038

Ziyan, M. (2020). Üniversite öğrencilerinin kariyer uyumlarını yordamada psikolojik sağlamlık, bilişsel esneklik ve proaktif kişiliğin rolü (Yayımlanmamış yüksek lisans tezi). Çukurova Üniversitesi, Adana.

Walsh, F. (2006). Strengthening family resilience (2nd ed.). Guilford Publications.

Werner, E. E. (1995). Resilience in development. Current Directions in Psychological Science, 4(3), 81 85. https://doi.org/10.1111/1467-8721.ep10772327

Windle, G. (2011). What is resilience? A review and concept analysis. Reviews in clinical gerontology,21(2), 152-169. https://doi.org/10.1017/S0959259810000420

World Health Organization [WHO]. (2020). UN Policy Brief on COVID-19 and the need for action on mental health. https://www.who.int/emergencies/diseases/novelcoronavirus-2019/events-as-they-happen 